
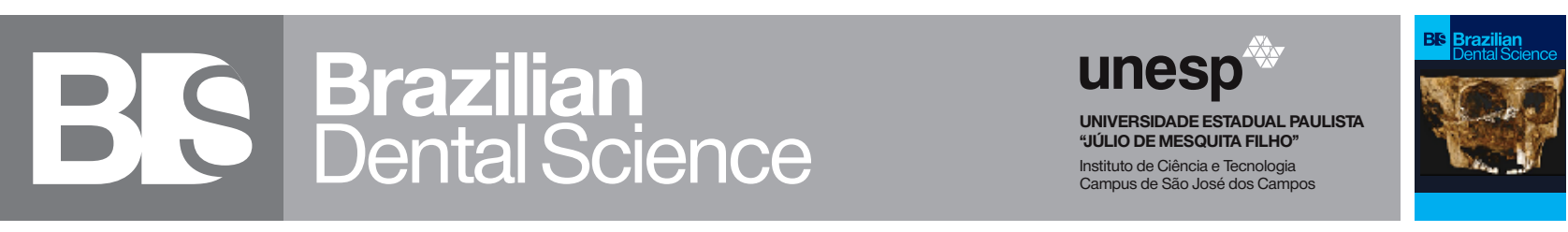

\title{
Pictograph system for diagnosis making and data management in endodontics
}

\author{
Sistema de pictograma para elaboração de diagnóstico e gerenciamento de dados em endodontia
}

Amjad Abu HASNA ${ }^{1}$, Alana Barbosa Alves PINTO ${ }^{1}$, Giovanna Bignoto MINHOTO ${ }^{1}$, Bruna Jordão Motta CORAZZA ${ }^{1}$, Cláudio Antonio Talge CARVALHO ${ }^{1}$, Carlos Henrique FERRARI ${ }^{1}$

1 - São Paulo State University (Unesp) - Institute of Science and Technology, São José dos Campos -Department of Restorative Dentistry Endodontic Division - São José dos Campos - SP - Brazil.

\section{ABSTRACT}

Objective: this questionnaire aimed to evaluate the approval of a new pictograph system for endodontic diagnosis by undergraduate and graduate students/ endodontist instead of a conventional method. Methods: after a presentation to a total of 224 participants explaining the pictograph system, the participants (166 undergraduate students and 58 graduate students/endodontist) received a standardized questionnaire with three questions. The data were analyzed using the multprop macro basing on Tukey's test for multiple comparison with ( $\mathrm{P} \leq 0.05)$. The first question was to define the education level of the participants; the second question about which diagnosis method is preferred; and the third question about the intention of using one of the methods in the future. The questionnaire was realized in May 2019. The response rate was 97.7\%. Results: the first question showed that $74.10 \%$ and $25.90 \%$ were undergraduate and graduate students/ endodontist respectively. After statistical analysis there was no significant difference between the groups in the second and the third questions. In the second question (71.08\% and 62.06\%) of undergraduate and graduate student/endodontists respectively preferred the pictograph method over the conventional method. In the third question (60.24\% and 51.72\%) of undergraduate and graduate student/endodontists respectively showed interest in using the pictograph method in their professional career. Conclusion: the pictograph method in endodontic diagnosis is accepted by the majority of undergraduate and graduate students/endodontists. Training and experience affect the diagnosis making.

\section{KEYWORDS}

Advanced dental education; Continuing dental education; Endodontics; Pictograph.

\section{RESUMO}

Objetivo: este questionário teve como objetivo avaliar a aprovação de um novo sistema de imagem para diagnóstico endodôntico por estudantes de graduação e pós-graduação / endodontista, em vez de um método convencional. Métodos: após uma apresentação a um total de 224 participantes explicando o sistema de pictograma, os participantes (166 estudantes de graduação e 58 de pós-graduação / endodontista) receberam um questionário padronizado com três perguntas. Os dados foram analisados usando a macro multipropósito baseada no teste de Tukey para comparação múltipla com $(\mathrm{P} \leq 0,05)$. A primeira pergunta foi definir o nível de escolaridade dos participantes; a segunda pergunta sobre qual método de diagnóstico é preferido; e a terceira pergunta sobre a intenção de usar um dos métodos no futuro. O questionário foi realizado em maio de 2019. A taxa de resposta foi de $97,7 \%$. Resultados: a primeira pergunta mostrou que $74,10 \%$ e $25,90 \%$ eram estudantes de graduação e pós-graduação / endodontista, respectivamente. Após análise estatística, não houve diferença significativa entre os grupos na segunda e na terceira questões. Na segunda questão $(71,08 \%$ e $62,06 \%$ ) dos estudantes de graduação e pós-graduação / endodontistas, respectivamente, preferiram o método de pictograma ao método convencional. Na terceira questão (60,24\% e 51,72\%) dos estudantes de graduação e pós-graduação / endodontistas, respectivamente, demonstraram interesse em utilizar o método de pictograma em sua carreira profissional. Conclusão: o método do pictograma no diagnóstico endodôntico é aceito pela maioria dos estudantes de graduação e pósgraduação / endodontistas. Treinamento e experiência afetam a elaboração do diagnóstico.

\section{PALAVRAS-CHAVE}

Educação odontológica avançada; Educação continuada em odontologia; Endodontia; Pictograma 


\section{INTRODUCTION}

$\mathrm{T}$ he process to make a diagnosis of a pulp pathology consists of several steps in an established order, producing a series of data reported by clinical examination and radiographical findings [1]. However, this diagnosis is affected by the different professionals' experiences and specialties $[2,3]$. There is no doubt that the right diagnosis of a pulp pathology leads to the most feasible treatment planning, whether to preserve a tooth or to extract and replace it with an implant among a variety of treatment options [4-6].

It is a challenge for both undergraduate and graduate students, as well as for general practitioners and endodontists, to make a decision or a diagnosis [7-10] due to variety of data about pain characteristics, intensity, and stimulators; clinical signs and symptoms; and radiographic findings that should be collected prior to diagnosis making [11]. As well as, there is no standardization of these data in clinical and medical records which facilitates the understanding of clinical cases in initial and post-operative care.

However, digital technology can improve learning effectiveness and develop pedagogical practices more adapted to today's students [12]. New generations are increasingly more familiar with the use of symbology [13] making the use of digital technology more popular $[14,15]$.

Pictograph are symbols used to convert messages and ideas into images that are clear and easy to understand without the use of text [16]. Relevant data of endodontic diagnosis can be converted into pictographs and grouped in three categories: pain characteristic (intensity, type, stimulator, location, duration and decline), clinical examination and radiographic examination. It would be sufficient to combine these data represented by an organized set of pictographs to provide a more accurate diagnosis and this results in a more objective treatment planning [12].
In order to enhance the dental students learning and facilitate the endodontic diagnosis making, this study aimed to evaluate the comprehension of a new pictograph system for endodontic diagnosis among undergraduate and graduate students/endodontists, as well as the intention of using it posteriorly.

\section{MATERIAL AND METHODS}

\section{The questionnaire}

This study was realized at São Paulo State University, Institute of Science and Technology after approval of the research ethics committee (no 3.579.433).

To construct this questionnaire, an initial formulate was elaborated and presented to six students selected randomly to evaluate the ease of comprehension and interpretation. Once validated, a new formulate was elaborated considering the results of the initial one in improving the last one. The questionnaire was then destinated for undergraduate students (matriculated in pre-clinical and clinical disciplines of endodontics) and graduate students (Stricto sensu and Lato sensu) and endodontists.

A total of 224 participants were involved in this study and divided into two groups (Group 1: undergraduate students $=166$ and group 2 : endodontists and graduate students $=58$ ). The participants received a presentation of the new pictograph system and then received the standardized questionnaire of three questions (Box.1).

Box 1 - The final questionnaire presented to the participants.

\begin{tabular}{|c|c|c|}
\hline Question & Answer 1 & Answer 2 \\
\hline $\begin{array}{l}\text { 1. Which is the level of your edu- } \\
\text { cation? }\end{array}$ & $\begin{array}{l}\text { Undergraduate } \\
\text { student }\end{array}$ & $\begin{array}{l}\text { Graduate stu- } \\
\text { dent/Endodontist }\end{array}$ \\
\hline $\begin{array}{l}\text { 2. Which endodontic diagnostic } \\
\text { method did you like? }\end{array}$ & $\begin{array}{l}\text { The conventio- } \\
\text { nal method }\end{array}$ & $\begin{array}{l}\text { The pictograph } \\
\text { method }\end{array}$ \\
\hline $\begin{array}{l}\text { 3. Which endodontic diagnostic } \\
\text { method you will use in your ca- } \\
\text { reer after completing the course } \\
\text { (conventional or pictograph)? }\end{array}$ & $\begin{array}{l}\text { The conventio- } \\
\text { nal method }\end{array}$ & $\begin{array}{l}\text { The pictograph } \\
\text { method }\end{array}$ \\
\hline
\end{tabular}




\section{The conventional method of endodontic diagnosis}

In this method, normally, dentists and dental students used to question the patient and fill in some standardized diagnostic sheets in order to obtain a final diagnosis of the pulp pathology. This method depends mainly on writing or typing the data collected by the patient for posterior analysis and diagnosis making.

\section{diagnosis}

The pictograph method of endodontic

The same way in questioning the patient as in the conventional method. However, the clinical signs and symptoms and the radiographical findings are represented by symbols.

The symbols are grouped in three categories with the following items:

1. Pain characteristics subdivided into six groups of symbols (Figure 1)

1.1 The intensity: no pain, mild or severe;

1.2 The type: provoked or spontaneous;

1.3 The stimulator: cold or hot stimulator;

\subsection{The location: localized or diffused;}

1.5 The duration: intermittent or continuous;

1.6 The decline: rapid decline or slow decline.

2. The clinical examination data subdivided into four groups (Figure 2)

2.1 The thermal test: positive response by cold stimulator, positive response by cold stimulator characterized by fast decline, positive response by cold stimulator characterized by slow decline and positive response by hot stimulator;

2.2 The percussion test: positive response;

2.3 The digital palpation test: positive response;

2.4 The mobility test: pain on movement.

3. The periapical radiographic image (normal image, diffuse radiolucent image, circumscribed radiolucent image) (Figure 3 ).
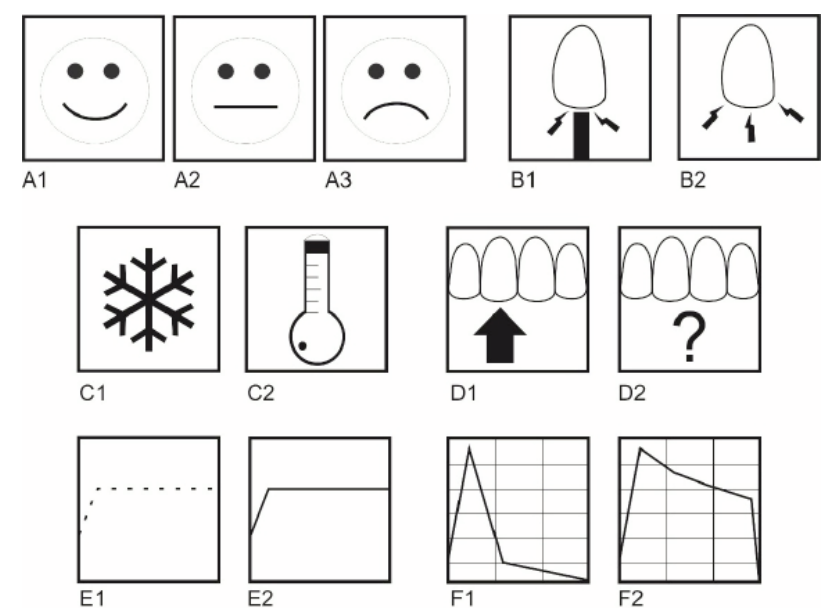

Figure 1 - The pain characteristics.

The intensity: A1) no pain, A2) mild or A3) severe; pain type: B1) provoked, or B2) spontaneous; the stimulator: C1) cold stimulator, or C2) hot stimulator; the location: D1) localized, or D2) diffused; the duration: E1) intermittent, or E2) continuous; the decline: F1) rapid decline, or F2) slow decline.

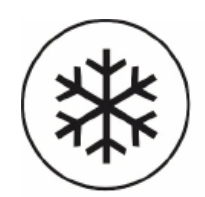

A1

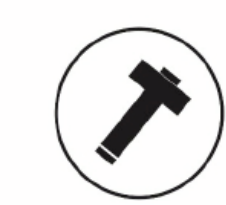

C

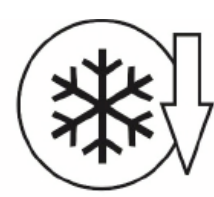

A2

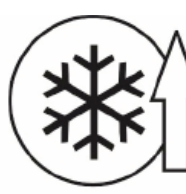

A3

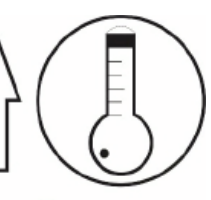

B

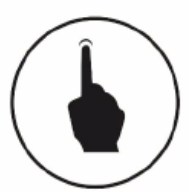

D

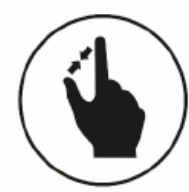

E
Figure 2 - The clinical examination data.

The thermal test: A1) positive response by cold stimulator, A2) positive response by cold stimulator characterized by fast decline, A3) positive response by cold stimulator characterized by slow decline, B) positive response by hot stimulator; $C$ ) positive response by the percussion test; D) positive response by the digital palpation test; E) pain on movement by the mobility test. 


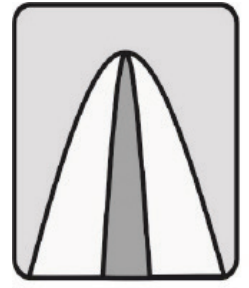

A1

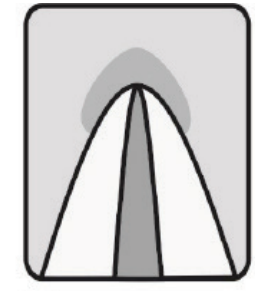

A2

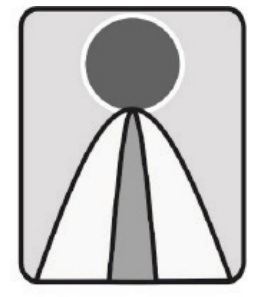

A3
Figure 3 - The periapical radiographic image.

A1) normal image; A2) diffuse radiolucent image; A3) circumscribed radiolucent image.

The professional while collecting the patient's data will use the $(\mathcal{})$ symbol over the selected option. Later, these data will be analyzed by the professional and the diagnosis will be obtained. (Figure 4). This form could be used in digital or manual medical records.

The pictographs were elaborated using Corel Draw software (CorelDRAW, Ontario, Canada).

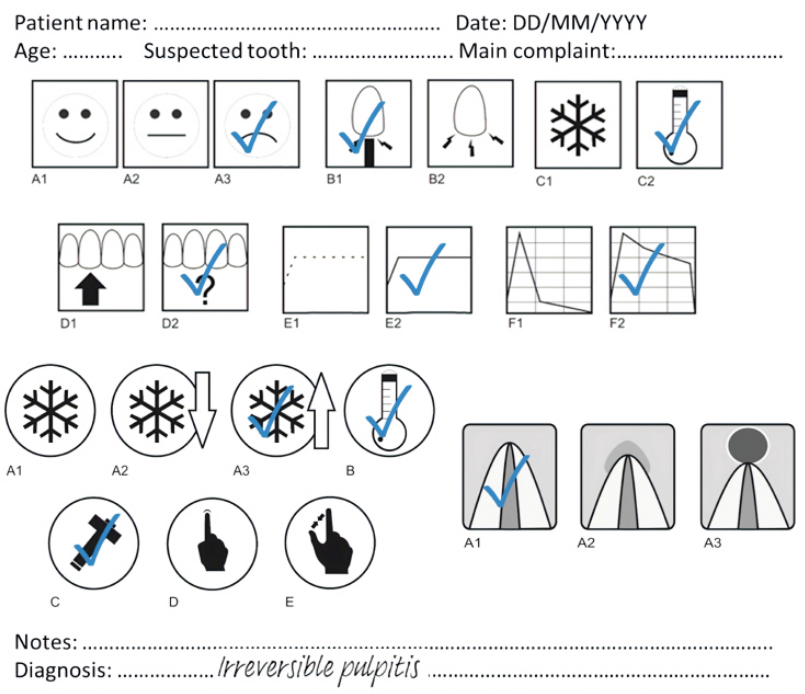

Figure 4 - Example of using the pictograph system in paper form.

\section{Statistical analysis}

The questionnaire data were collected and analyzed through multprop macro [17] using Tukey's honest significant difference test with $\mathrm{P} \leq 0.05$. In the second and third questions, the answer "The pictograph method" was considered as success or right answers. The data were analyzed by Minitab (Minitab ${ }^{\circledR}$ 17.1.0, by Microsoft, USA).

In the first question, no statistical analyzing was realized, however, the percentage of the participants of each group was calculated.

\section{RESULTS}

The first question was to determine the level of education of the students in which $74.10 \%$ and $25.90 \%$ were undergraduate and graduate students/endodontists respectively.

In the second and third questions, after statistical analysis there was no significant difference between the groups in which in the second question: $71.08 \%$ and $62.06 \%$ of undergraduate and graduate student/ endodontists respectively preferred the pictograph method over the conventional diagnosis method, and in the third question: $60.24 \%$ and $51.72 \%$ of undergraduate and graduate students/endodontists respectively showed interest in using the pictograph method instead of using the conventional diagnosis method after graduation and in their professional career (Table.1).

Table 1 - The percentage of the answers related by both groups.

\begin{tabular}{|c|c|c|c|c|}
\hline Questions & $\begin{array}{r}\text { Underg } \\
\text { stud }\end{array}$ & $\begin{array}{l}\text { raduate } \\
\text { ents }\end{array}$ & $\begin{array}{r}\text { Gra } \\
\text { stud } \\
\text { Endoc }\end{array}$ & $\begin{array}{l}\text { duate } \\
\text { ents / } \\
\text { ontists }\end{array}$ \\
\hline \multirow{2}{*}{$\begin{array}{l}\text { Which is the level of your } \\
\text { education? }\end{array}$} & \multicolumn{2}{|c|}{$74.10 \%$} & \multicolumn{2}{|c|}{$25.90 \%$} \\
\hline & $\begin{array}{l}\text { Conven- } \\
\text { tional }\end{array}$ & $\begin{array}{l}\text { Picto- } \\
\text { graph }\end{array}$ & $\begin{array}{l}\text { Conven- } \\
\text { tional }\end{array}$ & $\begin{array}{l}\text { Picto- } \\
\text { graph }\end{array}$ \\
\hline $\begin{array}{l}\text { Which endodontic diagnostic } \\
\text { method did you like? }\end{array}$ & $28.92 \%$ & $71.08 \%$ & $37.94 \%$ & $62.06 \%$ \\
\hline $\begin{array}{c}\text { Which endodontic diagnostic } \\
\text { method you will use in your } \\
\text { career after completing the } \\
\text { course? }\end{array}$ & $39.76 \%$ & $60.24 \%$ & $48.28 \%$ & $51.72 \%$ \\
\hline
\end{tabular}

\section{DISCUSSION}

The use of pictograph instead of written orders or messages has long been used in organized societies. This use tends to be even greater for new generations with the digital 
technology's revolution as applications and social networks. Currently digital technology is gaining a greater space in dental courses teaching through mobile applications [15] and virtual teeth [14].

In medical sciences, including medicine and pharmacy, pictographs are used to explain prevention and treatment information for patients [18] but with little focus on professional education and data organization in medical records. However, in dentistry and more specifically in endodontics, this use seems to be scarce. It is recommended to use pictographs in medical risk communication to improve people's risk comprehension and decision making [19].

This study presents a complete system to organize the endodontic diagnosis data. This system permits a more objective teaching, a more practical data organization, an easier communication among dental teachers, dental students and dentists in general, as the interprofessional communication in the field of dentistry affects patient satisfaction [20].

In this study, a questionnaire was made to evaluate the comprehension of a new pictograph system for diagnosis of pulp pathology among undergraduate and graduate students/endodontists. The results showed that undergraduate students were more open to accept the pictograph method. This group commented that the comprehension of the pictograph system was easier than the conventional method.

Pineda et al. [21] related that undergraduate decision-making is affected by academic training, in a study evaluated the undergraduate diagnosis of 15 endodontic cases after completing the endodontic discipline and one year later after completing their studies in implantology. The same results could be related in the present study, in which the training influences the decision-making. In this study, both groups received a presentation to clarify the definition of pictograph method and how it works.
In this study the graduate students/ endodontist were less interested than the undergraduate students in which fewer students selected the pictograph method in comparison to the undergraduate student's group. Still, the majority selected the pictograph method in both groups. This may be related to the experience of graduate students/endodontist having in diagnosis making and being more familiar with the conventional method. In this aspect, in a study evaluated the effects of specialty background and professional experience on decision making in endodontic diagnosis and treatment planning among professionals of diverse specialties, the endodontists showed the most consistent agreement among the specialty groups [2]. Even more in another study, a survey was realized to compare factors influence root canal retreatment strategies between dental specialists and general practitioners and found that the specialists decision making is affected by the experience as well [3].

On the other hand, 28.92 and $37.94 \%$ of undergraduates and graduate students/ endodontist respectively selected the conventional method instead of pictograph method. Even more, some participants selected the pictograph method in the second question, however, in the third question declared no intention to use the pictograph method in their professional career. The negative response of some participants may be related to misunderstanding of the symbols, in this order, adoption requires education and consistency of use and placement [22].

\section{CONCLUSIONS}

Within the limitation of this study, the pictograph method in endodontic diagnosis is accepted by the majority of undergraduate and graduate students/endodontists. Training and experience affect the diagnosis decision.

\section{Acknowledgement}

The authors deny any conflict of interest. 


\section{REFERENCES}

1. Torabinejad M, Goodacre CJ. Endodontic or dental implant therapy: the factors affecting treatment planning. J Am Dent Assoc. 2006;137(7):973-1028. doi:10.14219/jada.archive.2006.0318

2. McCaul LK, McHugh S, Saunders WP. The influence of specialty training and experience on decision making in endodontic diagnosis and treatment planning. Int Endod J.2001;34(8):594-606. doi:10.1046/.13652591.2001.00433.x

3. Wenteler GL, Sathorn C,Parashos P.Factors influencing root canal retreatment strategies by general practitioners and specialists in Australia. Int Endod J. 2015;48(5):417-27. doi:10.1111/iej.12330

4. Zitzmann NU, KrastI G, Hecker H, Walter C, Waltimo T, Weiger R. Strategic considerations in treatment planning: deciding when to treat, extract, or replace a questionable tooth. JProsthetDent. 2010;104(2):80-91. doi:10.1016/ S0022-3913(10)60096-0

5. Pagonis TC, Fong CD, Hasselgren G. Retreatment decisions--a comparison between general practitioners and endodontic postgraduates. J Endod. 2000;26(4):240-1. doi:10.1097/00004770-200004000-00012

6. Dechouniotis G, Petridis XM, Georgopoulou MK. Influence of specialty training and experience on endodontic decision making.J Endod. 2010;36(7):1130-4 . doi:10.1016/j.joen.2010.03.023

7. Rodríguez G, AbellaF,Durán-Sindreu F,PatelS, Roig M. Influence of cone-beam computed tomography in clinical decision making among specialists. J Endod. 2017;43(2):194-199. doi:10.1016/j.joen.2016.10.012

8. Patients' values related to treatment options for teeth with apical periodontitis. JEndod. 2016;42(3):365-70. doi:10.1016/j.joen.2015.11.022

9. Aminoshariae A, Teich S, Heima M, Kullid JC. The role of insurance and training in dental decision making.JEndod. 2014;40(8):1082-6. doi:10.1016/j. joen.2014.05.007

10. Kvist T, Heden G, Reit C. Endodontic retreatment strategies used by general dental practitioners. Oral Surg Oral Med Oral Pathol Oral Radiol Endod. 2004:97(4):502-7.doi:10.1016/j.tripleo.2003.09.006

11. Evans N, Hayes J. Textbook of Endodontology. Int Endod J. 2005 Dec;38(12):949-949. doi:10.1111/j.1365-2591.2005.01039.x.
12. InquimbertC, Tramini P,Romieu 0, Giraudeau N. Pedagogical evaluation of digital technology to enhance dental student learning. Eur J Dent. 2019;13(1):53-7. doi:10.1055/s-0039-1688526

13. Gramling R, Anthony D, Frierson G,Bowen D. The cancer worry chart: a single-item screening measure of worry about developing breast cancer. Psychooncology.2007;16(6):593-7.doi:10.1002/pon.1128

14. de Boer IR, Wesselink PR, Vervoorn JM. The creation of virtual teeth with and without tooth pathology for a virtual learning environment in dental education. Eur JDentEduc. 2013;17(4):191-7. doi:10.1111/eje.1202

15. de Oliveira MLB, Verner FS, Kamburog-lu K, Silva JNN, Junqueira RB. Effectiveness of using a mobile app to improve dental students' ability to identify endodontic complications from periapical radiographs. J DentEduc. 2019;83(9):1092-9. doi:10.21815/JDE.019.099

16. Ben-Moshe L, Powell JJW. Sign of our times? Revis(it)ing the International Symbol of Access. Disabil Soc. 2007 Aug 31;22(5):489-505. doi: 10.1080/09687590701427602

17. Abu Hasna A, Ferrari CH, Bittencourt TS, Camargo CHR, Carvalho CAT. Acting and knowledge of emergency rescue teams in dental trauma. Brazilian Dent Sci. 2019 Jul 30;22(3):329-34. doi:10.14295/bds.2019.v22i3.1717.

18. Usher-Smith JA, Masson G, Mills K, et al. A randomised controlled trial of the effect of providing online risk information and lifestyle advice for the most common preventable cancers: study protocol. BMC Public Health. 2018;18(1):796. Published 2018 Jun 26. doi:10.1186/s12889-018-5712-2

19. Kreuzmair C,Siegrist M, Keller C. Does iconicity in pictographs matter? The influence of iconicity and numeracy on information processing, decision making, and liking in an eye-tracking study. Risk Anal. 2017;37(3):546-56. doi:10.1111/risa.12623

20. Hamasaki T,Kato H, Kumagai T,Hagihara A. Association between dentistdental hygienist communication and dental treatment outcomes. Health Commun. 2017;32(3):288-97.doi:101080/10410236.2016.1138376

21. Pineda K, Bueno R, Alvarado C, Abella F, Roig M, Duran-Sindreu F. Influence of academic training in endodontics and implantology on decision-making in undergraduate students. AustEndod J. 2018;44(1):40-5. doi:10.1111/aej.12208

22. Barstow BA, Vice J, Bowman S, Mehta T, Kringen S, Axelson P, etal. Examining perceptions of existing and newly created accessibility symbols. Disabil Health J.2019;12(2):180-6. doi:10.1016/.d.dhjo.2018.11.012

\section{Amjad Abu Hasna \\ (Corresponding address)}

Av. Eng. Francisco José Longo, 777, Jardim São Dimas, 12245000 -

São José dos Campos, SP - Brazil.

Date submitted: 2020 Feb 14

E-mail: d.d.s.amjad@gmail.com 